\title{
Trinitarian Perception
}

\author{
Mark Eli Kalderon
}

\begin{abstract}
We begin with a puzzle about how to intelligibly combine the active and passive elements of perception. For counsel, we turn to Augustine's account of perception in De trinitate. Augustine's trinitarian account of perception offers an attractive resolution of our puzzle. Augustine's resolution of our puzzle, however, cannot be straightforwardly adopted. It must be adapted. We end with speculation about how this might be done.
\end{abstract}

I Aporia. Placed behind a protective grill facing the pavement on III Cannon Street resides the London Stone, or what remains of it. Composed of oolitic limestone, the London Stone is an unremarkable sight. The bronze plaque on the casing, however, ends on an enigmatic note, "Its origin and purpose are unknown but in II 88 there was a reference to Henry, son of Eylwin de Lundenstane, subsequently Lord Mayor of London". Though its origin and purpose are forgotten, the degraded remnant of what is most likely a Roman structure has exercised an enduring pull on the literary imagination. Thus in Henry vI, Part 2, Shakespeare envisions Jack Cade, having led a rebellion and established himself as the Mayor of London, sitting astride the London Stone administering rough justice. In ferusalem, William Blake casts it, instead, as a sacrificial alter of Druidic origin:

Where Albion slept beneath the Fatal Tree

And the Druids golden Knife,

Rioted in human gore,

In Offerings of Human Life

They groan'd aloud on London Stone

I am struck by the contrast between the unremarkable sight of the small block of limestone with its obscurity and continuing power over the imagination (it figures, for example, in China Miéville's Kraken). And though these sentiments are somewhat in tension, it seemed at once poignant, the unimpressive degraded remains of a once great thing, and yet to intimate some unseen power, as if somehow some greatness remained, latent and dormant, within. 
Walking down Cannon Street, I turn, and look, and see the ancient stone. In the natural history of my so seeing, the stone, the object of my perception, figures prominently as a causal antecedent. The stone presents a rough appearance because the stone has that surface prior to its so appearing. And its rough gray surface, illuminated from above by the light of its casing, causes me to see that surface. This observation is perhaps the source of the long tradition of thinking of perception as a passive capacity. It is plausible, at the very least, that it is a materially necessary condition on a subject perceiving an object that the relevant sensory organs of the subject be acted upon, however mediately, by that object. Thus the London Stone must mediately alter my eyes - changing patterns of retinal stimulation, say-by altering the light in a complex subatomic process occurring at or near its surface.

I turn, and look, and see the ancient stone. The London Stone mediately acts upon my eyes by acting upon the illumination. And this is part of the natural history of my seeing the stone. Not only must my eyes be mediately acted upon by the stone, but my seeing the stone is an experience that I undergo. Even though my seeing of the stone is an experience that I undergo as a result of the stone mediately acting upon my eyes, my seeing of the stone is not something done to me by the stone. It is $I$ that see the stone. It is I, and not the stone, that is doing the seeing. Even acknowledging the passive elements in the natural history and phenomenology of my perception (that the stone is the cause of my seeing it and that my seeing it is an experience that I undergo), there is a residual active element in my seeing. The stone may make itself seen, but my seeing of the stone is activity properly attributed to me and not the stone.

How are we to understand this?

For counsel we turn to Augustine's account of perception in De trinitate. "And God said, Let us make man in our image, after our likeness" Genesis r:26. Noting God's use of the plural form, Augustine understands a human being, or at least their inner spiritual nature, to be an image and likeness of the Trinity, the Father, Son, and Holy Spirit. De trinitate, rather nicely, itself constitutes a trinity consisting in three parts. In the first part, books $\mathrm{I}^{-} 4$, Augustine reviews the scriptural evidence for the doctrine of the Trinity. In the second part, books 5-7, Augustine explains how there may be three equal persons each identical to the whole of a substance in terms of his theory of relations. In the third part, books 8-15, Augustine applies these results to the human mind conceived as an imago Dei. And it is in the context of the project of this third part, to understand the human mind as an image of the trinitarian God, that Augustine provides an account of perception in book II.

II The Perceptual Trinity. Augustine distinguishes three elements in perception. Though Augustine's example is vision, which he regards as exemplary, the trinitarian structure is meant to be exhibited by any perceptual apprehension of the 
external world:

When we see a body, we have to consider and to distinguish the following three things, and this is a very simple task: first, the object which we see whether a stone, or a flame, or anything else that can be seen by the eyes, and this could of course, exist even before it was seen; secondly, the vision, which was not there before we perceived the object that was presented to the sense; thirdly, the power that fixes the sense of sight (sensus occulorum) on the object that is seen as long as it is seen, namely, the attention of the mind (animi intentio) (Augustine, De trinitate, II 2 2; Matthews and McKenna 2002, 6I-62)

In this passage, Augustine distinguishes between three things: (I) the object of perception, (2) perception, and (3) the attention of the mind (animi intentio).

Let's consider these in turn:

(I) The object of perception. The objects of at least visual perception include bodies and corporeal activities such as a stone or a flame. Moreover, Augustine at least suggests that the objects of visual perception may include entities from other ontological categories so long as they can be seen by the eyes. Augustine subscribes to a form of perceptual realism where the objects of perception may exist prior to perception (in contrast, for example, to the Secret Doctrine that Socrates attributes to Protagoras where the object of perception and the perceiver's perception of it are "twin births", Plato, Theaetetus, $156 \mathrm{a}-\mathrm{b}$ ). It is reasonable to suppose that the priority of the object of perception is both temporal and existential.

(2) Perception. The second element, "vision", should not be understood as sight, the power to see, but rather its exercise, seeing. What was absent before the perceiver saw the object was not their power to see. Otherwise, it would not have been possible to come to see what they did, for they would have been blind. What was absent was not sight, but the seeing of the thing. It is not yet clear what Augustine takes perceptual activity to be. All we know so far is that it is the exercise of the soul's perceptual power and may take as an object a distal body or corporeal activity that is temporally and existentially prior to its perception. Augustine soon elaborates though, claiming that vision just is the sense in-formed by the perceived body or corporeal activity.

(3) The attention of the mind (animi intentio). So far, Augustine's enumeration of the elements of perception has been reasonably familiar. We have been asked to distinguish the object of perception from the perception of it, at least as a perceptual realist would understand these notions. The real novelty of $\mathrm{Au}^{-}$ gustine's trinitarian account is the insistence on the third essential element 
involved in perceptual apprehension, animi intentio. Animi intentio means something like concentration or conscious attention. Augustine evidently believes that perception involves consciously attending to the object of the perceptual experience. Moreover, animi intentio is conceived by Augustine to be the activity of a cognitive power. Augustine conceives of this power as the will of the soul to direct the mind to various objects. This activity does three things. It directs the sense outward toward the distal body. It fixes the sense on that body and so gives rise to vision. It also sustains that vision - animi intentio fixes the object of perception for so long as it is seen. (On intentio in Augustine's account of perception generally, see O'Daly I987, chapter 3.2)

Having enumerated the elements of the perceptual trinity, Augustine immediately notes an important disanalogy with the archetype. The Father, Son, and Holy Spirit are, crucially, one substance (understood as being or essentia, if not as a substratum, which would be inconsistent with Divine Simplicity, De trintate 75 ro). That God is three persons may be a truth of revealed theology, but Divine Unity is a truth of natural theology discoverable by reason. However, the perceptual trinity involves two substances: $(\mathrm{I})$ the object of perception understood as a body or corporeal activity independent of the perceiver and (2) the living substance to whom the power of sight and its visual activity belong. The substance to which sense and vision belong, the living being, is a distinct substance from the material body or corporeal activity perceived, excepting, of course, when the perceiver sees a part of their own body, as when gazing at their hand. The disanalogy arises because perception is a trinitarian structure pertaining to the outer man. (On the distinction between the inner and outer man see Paul 2 Corintbians 4:I6, Plato Republic 9 589 a 7, and Plotinus Ennead I I IO 15, 5 I IO Io.)

The psychological capacities associated with the outer man include perception, memory, and imagination and are shared with non-rational animals. The exercise of memory or imagination may not require the presence of a body in the natural environment the way that perception does, but they retain a connection to the sensible and the corporeal through their dependence upon perception. Remembering a body may occur in that body's absence, but what is remembered derives from the image and likeness of the form of the body that previously arose in vision. Similarly the elements of imagination derive from images formed in perceiving bodies. Indeed, Augustine regards the soul's preoccupation with the corporeal in its absence, made possible by memory and imagination, to be a greater ethical challenge than the senses' presentation of the corporeal and, in general, living solely by the trinities of the outer man is wicked and shameful. It is the outer man's involvement with the corporeal that gives rise to the divergence from the archetype: "Wherefore this trinity is not an image of God, for it is produced in the soul itself through the sense of the body from the lowest, that is, from the corporeal creature, to 
which the soul is superior" (De trinitate II 58 , Matthews and McKenna 2002, 70). No such divergence will arise for the trinitarian structures pertaining, instead, to the psychological capacities of the inner man. Only the inner man, the rational soul, is an image of God. Nevertheless, the trinitarian structure of perception, while not itself an imago Dei, is like the Trinity, however imperfectly, for vestigial traces of the Trinity can be found in all created things (De trinitate II I I, for discussion of imago Dei as conceived by Augustine see Gioia 2008, chapter II).

Consider the case of seeing a body such as a stone. Though the object of perception and the sense and vision differ in nature, since the object is an inanimate body and the perceptual power and its activity belong to the distinct substance of the living being, they are nevertheless united in perception. Like the Trinity, of which perception is a pale shadow, perception is a genuine unity. The object is united with the sense in vision, despite their difference in nature. That a perceived body and the sense that unites with it in perception differ in nature suggests that their unity is subject to further explanation if genuinely intelligible. To get that explanation into view, we must first understand how the elements of the perceptual trinity are arranged in ascending order of ontological dignity, and the explanatory relationships that obtain among them.

The object of perception, the stone, is a body. Moreover, it is an inanimate body. No life inheres in the stone as it lacks a soul, and the soul is the principle of life. Here we have a contrast with Cartesian dualism. While, for Augustine, the soul is inextended and incorporeal, it is also, importantly, living, in a way that it is not for Descartes. The sense that unites with the stone in the seeing of it, though bodily - it involves the eyes, and so belongs to the outer man - is animate and so not completely corporeal. By the sense, Augustine means the corporeal sense organ and the sensitive soul that animates it. The sensitive soul in animating the eyes affords the perceiver the capacity of sight. Augustine describes the compound as a mixture, though it is doubtful that he means anything akin to a physical mixture. Thus, Augustine claims that the soul is stretched throughout the body, not by means of a local diffusion, but by a vital intention (Epistula 1662 4; compare also Porphyry Sentenciae 3). However this mixture is to be understood, unlike the stone, the sense that unites with that inanimate body is a living body compounded of the corporeal sense organ and the sensitive soul that animates it. In contrast with the body and the sense that unites with it, the animi intentio is completely incorporeal. Animi intentio is the exercise of a power of the incorporeal soul. Though, on the trinitarian account, animi intentio is an essential element of perception, should the perceiver lose their sense, by being blinded in an injury say, they would retain this power. It is just that, with the loss of sight, this power could no longer be directed upon the visible through the eyes. Thus the elements of the perceptual trinity are arranged in ascending order of ontological dignity, from the corporeal 
to a compound of the corporeal and the spiritual to the spiritual.

Assigning the elements of the perceptual trinity roles loosely analogous with the Father, Son, and Holy Spirit reveals explanatory relationships between them. Moreover, doing so introduces some refinements:

Since this is so, let us recall how these three, though differing in nature, may be fitted together into a kind of unity, namely, (i) the form of the body that is seen, (ii) its image impressed on the sense, which is vision, or the sense informed, and (iii) the will of the soul which directs the sense to the sensible thing and keeps the vision itself fixed upon it. (Augustine, De trinitate, II 25; Matthews and McKenna 2002, 65)

Let us begin with a refinement concerning the object of perception. When the trinitarian account is first introduced, the object of perception is clearly presented as a body or corporeal activity. Later Augustine speaks of the object of perception as the form of the body (forma corporis). Moderns might see this as an invitation to undertake what Thompson Clarke described as a surface inquiry, but perhaps this is overhasty. Augustine's position seems to be that in seeing a body, the perceiver sees is the form of the body. And in seeing the form of the body the perceiver sees the body.

The refinement, here, allows Augustine to more clearly articulate the sense in in which the object of perception is the "parent" of perception (De trinitate II 59 ). The form of the body is the parent of perception insofar as perception involves the sense being in-formed by the form of the body seen. Seeing, the activity of the visual power, just is the in-forming of the sense in vision. What Augustine describes as vision just is the sense taking on the form of the body in an image and likeness of that form. The refinement was needed to more clearly articulate vision as a perceptual mode of formal assimilation. In vision, the sense assimilates to the form of the body and the body impresses its form upon the sense as in the Peripatetic analogy of the signet ring impressing a seal upon the wax (Aristotle, De anima 2 I2 $424^{a} \mathrm{I} 8-23$ ).

The form assimilated by the soul is an image and likeness of the body and is distinct from the form of the body, though these are indiscernable in ordinary cases of perceptual experience. After all, when the ring is still impressed upon the wax, we cannot distinguish the image in the wax from the form of the ring- the seal is only revealed once the ring is removed (De trinitate II 23 ). Though indiscernable in ordinary perception, reason can distinguish the form of the body from its image by reflecting upon the phenomena of after images and double vision (De trinitate II $24)$. In the case of after images, the image and likeness of the body persists for a time after the form of the body is no longer present, the body being removed from view. Thus the image and likeness, which persists despite the body's absence, must be distinct from the form of the body. 
The object of perception is the Father insofar as it begets its perception. Perception, then, would be the Son, leaving animi intentio as the Holy Spirit. However, as soon as he makes the crucial observation that determines the assignment of trinitarian roles, Augustine, importantly, qualifies it. It turns out that this qualification is the key to understanding the unity manifest by the perceptual trinity despite their difference in nature. The object of perception, the form of the body, is, at best, a quasi-parent and the perception, the subsequent vision, a quasi-offspring. Part of the point of the qualification is that the object of perception is not a total cause of the perception. The sense may assimilate to the form of the body in vision. That is part of what licenses us to speak of the body as a quasi-parent and the vision as quasi-offspring. But the body is causally insufficient for the occurence of vision. Augustine's idea is that in order for the form of the body to impress the sense, the sense must first be applied to the body. Animi intentio fixing the sense to the body is a necessary precondition for the sense to receive an image and likeness of the form of the body in vision. That is the function of Spirit in the guise of animi intentio.

This Augustinian doctrine, or a variant of it, will be subsequently expressed in an interesting metaphor of Robert Kilwardby's. Kilwardby gives a vitalist twist to the Peripatetic wax analogy by imagining life to inhere in the wax and to be actively pressing itself against the signet ring, De Spiritu Fantastico I03. The will of the active wax, I take it, is a late Scholastic avatar of Augustine's animi intentio. Kilwardby's image of active wax will be echoed by another late Scholastic Augustinian, Peter John Olivi, perhaps independently of Kilwardby, in 2uaestiones in secondum librum Sententiarum q. $5^{8} 45^{-1}$ - 6 , 506-7; q. 72 35-6. Augustine's animi intentio is an important source for Olivi's conception of aspectus, but Olivi may have been drawing on non-Augustinian sources as well such as Alhazen (see Tachau I988, 4I especially n. 43; for how Kilwardby and Olivi differently develop Augustinian materials see Silva and Toivanen 2010).

Augustine describes animi intentio as the will of the soul that directs the sense to the visible body. Animi intentio plays at least three distinct roles in the De trinitate account, (Silva, 20I4, 8I-82). First, the will of the soul directs the sense outwards toward a distal body. That is, animi intentio is the voluntary application of the visual sense to this distal body rather than some other. Or perhaps it voluntarily directs the sense at no thing in particular willing only to see what there is to see. It is thus operative prior to the sense's assimilation of the form of the body in vision. Compare this with the activity of the Inchoate Intellect in Plotinus' account of ontogenesis in the Fifth Ennead. The Incohate Intellect experiences its separation from the One as a profound loss. In seeking to reunite with the One, it turns, and looks, and sees only itself insofar as it is an image of the hyperontic One thus becoming the Intellect in full actuality and establishing the domain of intelligible 
being. Notice that before the Inchoate Intellect sees thus becoming the Intellect in full actuality, it must first turn and look. Second, animi intentio unites the sense with the body in order to see it. It thus fixes the content of perception by directing the sense upon the object of perception. But having fixed the content of perception by directing the sense upon the object of perception, it may not safely withdraw from the scene. Animi intentio is thus required, thirdly, to sustain that perception-it "keeps the vision itself fixed upon it".

The form of the body is a quasi-parent since it may only in-form the sense by the sense being applied to it by animi intentio. In perceiving a body, the body and sense are bound together. As a consequence of their being bound together the sense formally assimilates to the form of the body and forms an image and likeness of it. What binds the body and sense together despite their differing in nature-while the former is a body the latter is a compound of body and soul-is the spiritual activity of the will of the soul that directs the sense to that body and so binds them. It is the will's binding the sense to the body that constitutes the unity of the perceptual trinity.

The perceived stone is not the total cause of perception. In order for the stone to impress its form upon the sense, the sense must be applied to the body by the will of the soul. Animi intentio plays an indispensable role in the causal explanation of perception. These claims are consistent, nevertheless, with the perceived body playing a causal role in perception, even if it is not a total cause. So understood, the body causally cooperates with the sense directed by the will of the soul in the production of the image and likeness of it in vision. Moreover, by itself, this seems consistent with the perceiver being the agent in perception.

However, while the claims of De trinitate are consistent with the perceived body playing a causal role in perception, Augustine might also be read as denying that the body is a cause. Thus, Silva 2014, as part of a reading of De trinitate that seeks to reconcile it with the accounts of perception in De quantitate animae, De Genesi ad litteram, and De musica, argues for the stronger claim that not only is the body not causally sufficient, but that it is not even among the causes of perception. Silva argues for this on the basis of the soul's ontological superiority over the body and its expression in the body's inability to act upon the soul (for discussion of this principle in Augustine's thinking about perception see Brittain 2002). If Silva's (2014) reconciliationist reading is correct, then Augustine anticipates, in this way, Olivi's doctrine that the perceived object is a terminative cause and hence no efficient cause (on terminative causes see Kent 1984, I92-195, Pasnau I997, chapter 5.2, and Toivanen 2013, chapter 6).

Not all believe that a reconciliationist reading is so much as possible. Olivi, a thirteenth century Franciscan who drew heavily from Augustine in opposing the dominant Aristotelian framework, nevertheless felt free to depart from Augus- 
tine's views on perception, in part, because these were unsettled and inconsistent: "Concerning the act of the particular senses, Augustine said some things in the manner of someone uncertain wavering from one view to another" 2uaestiones in secondum librum Sententiarum q. 74, Pasnau I997, I3I. And later, William Crathorn will also express doubts about the consistency of Augustine's views about perception. Interestingly, his doubts turn on the present interpretive question. Crathorn complains that while in De Genesi ad litteram perception is active, in De trinitate Augustine says something contradictory (2uaestiones super librum Sententiarum q. I concl. I).

Let us set aside the consistency of Augustine's views about perception and so the possibility of a reconciliationist interpretation that Silva argues for. Let us also set aside the specific interpretive question about De trinitate, whether the perceived body plays a causal role in the formation of its image and likeness in vision. Let us, instead, consider the relative independent plausibility of these interpretations. I believe that there are good philosophical grounds for rejecting the strong claim that the perceived object plays no causal role in perception's formal assimilation to it.

The present worry is anticipated by Duns Scotus. Scotus at least presses a parallel point about the intellect in his Ordinatio and on the same general grounds. Though Scotus does not name names, Olivi is clearly a target as he reproduces a number of arguments from Olivi's Sentences commentary (Pasnau, I997, I48). Scotus concedes to Olivi that the object of the intellect could not be the complete cause of the intellectual act. However, Scotus insists that the object must play some causal role if the act of intellect is to be a likeness of it (Ordinatio I $334 \mathrm{n}$. 486). Generalizing, Scotus' idea is that the demands of formally assimilating to the object require that the object play an explanatory role inconsistent with being a terminative cause. It must at least be among the efficient causes. And it is the application of this general idea to the case of perception that constitutes the present worry (on Scotus on Olivi see Pasnau I997, chapter 4.4, on Scotus on cognitive powers, both sensory and intellectual, see Tachau I988, chapter 3, Spruit I994, 257-266, and Cross 2014, for a related worry see Pasnau I997, I74-175).

Scotus' general idea applied to the case of perception is this. Consider the will of the soul applying the sense to the body so that an image and likeness is formed in vision. As in Kilwardby's metaphor of the active wax, we can imagine the will of the soul pressing the sense against the body to form an impression of it. But, crucially, no impression will be formed as the result of this activity, if the body is incapable of resisting that activity insofar as it can. The sense's assimilation to the form of the body in vision is naturally understood as arising in the face of a countervailing force, the upshot of a conflict between the will's application of the sense and the body that resists it insofar as it can. It is hard to understand how the presence in the natural environment of a body which is the end and rest of the will 
that directs the sense toward it (De trinitate II 6) could determine the content of the perception, even if animi intentio directs the sense upon it. Somehow, the body must determine the content of the perception without itself being a determinant. But how could that be? If, for Augustine, perception is a mode of assimilation, then that which perception assimilates to must be explanatorily prior to perception in the sense that it is causally implicated in the formation of its image, even if it is not the total cause and not the primary agent of that process.

Consider, then, the trinitarian account so interpreted, where the body plays some causal role in the sense's assimilation to its form in vision. And set aside whether the trinitarian account, so interpreted, is of genuine Augustinian provenance (though Crathorn, for one, evidently thought it was). The trinitarian account, so interpreted, provides a nice resolution to the puzzle or aporia with which we began. Recall, that puzzle concerned how to intelligibly combine the active and passive elements in perception. The object of perception is a causal antecedent and the perceptual experience something the perceiver undergoes, and yet perceiving is something that the perceiver does and not something done to the perceiver. $\mathrm{Au}^{-}$ gustine's trinitarian account is well-placed to vindicate the residual active element in perception. Indeed, Augustine is often portrayed as at the head of a loose tradition that advocates an active conception of perception in contrast with the more passive conception associated with the Peripatetic tradition. (The contrast, how ${ }^{-}$ ever, is easy to exaggerate. Almost all Classical and Hellenistic theories include some active element in perception except, perhaps, for the Epicureans. For active theories of perception in the history of philosophy see Silva and Yrjönsuuri 20I4.)

That the will of the perceiver's soul binds the body and the sense together so that an image and likeness of the former arises in the latter is something that the perceiver does. The activity of animi intentio is properly attributed to the perceiver. It is not the stone that directs the sense upon it but the will of the soul of the perceiver. Not only is animi intentio properly attributable to the perceiver, but it also constitutes the unity of the perceptual trinity. Thanks to the activity of the will that directs the sense upon the body and so binds them, the body, the vision, and the will are united in a perceptual trinity. The role that Augustine assigns to the will in perception thus provides a straightforward sense in which perception is something the perceiver does as opposed to something done to the perceiver by the object of perception.

While the body is not causally sufficient for perception, the will must apply the sense to the body to initiate and sustain perception of it, and while the will is the primary agent of this activity, in order for the image and likeness of the form of the body to arise in the sense, the body must causally cooperate by resisting this activity insofar as it can. This was Scotus' insight about the explanatory demands of formal assimilation. The object to which the sense formally assimilates must 
be among the causes of that assimilation even if it is not the total cause, nor the primary agent of the interaction that leads to the formation of the image and likeness. Receiving the impression of the body is something the sense undergoes even if it is the result of the activity of the perceiver. That the sense's assimilation to the body is something that the sense undergoes is not only consistent with it being the result of the activity of the perceiver, there is a further, important insight of the trinitarian account. It is the activity of the perceiver, the will of the soul in directing the sense, that makes possible the sense's assimilation to its object by binding that sense to that object. The formal assimilation of sense to bodily form, that is, vision, is the consequence of this activity. The activity of the perceiver makes distal aspects of the natural environment perceptually accessible. That is one general lesson of Augustine's doctrine that animi intentio constitutes the unity of the perceptual trinity.

III Adapting the Augustinian Solution. The Augustinian solution to our aporia is attractive. Unfortunately, there is no real possibility of rolling back philosophical thinking to the fourth or fifth century, say, just as there is no real possibility of living "the life of a Bronze Age Chief, or a Medieval Samurai," in our present historical circumstances, as Williams (I98I, I4O) reminds us. Thus, there is no real question of straightforwardly adopting the Augustinian account as our own. The present historical circumstances, and the presuppositions of the present inquiry, are too alien for that. Can we, if not straightforwardly adopt, then, somehow adapt it for ourselves? I believe that, once we adjust the lighting somewhat, and remove some extraneous stage setting, what we will be presented with is the beginnings of a reasonable and attractive view.

We begin by dropping Augustine's dualism. I do not mean to be embracing, instead, monism, whether of a neutral, reductive, or anomalous variety, so much as suspending judgment about the issue. One effect of this is that we may not rely on principles that prohibit ontological inferiors from acting upon ontological superiors, for example. Instead, we shall adopt what might be described as a relaxed naturalism. And the present essay, being composed at what Dr Thomas Arnold, headmaster of Rugby, described as "the godless institution in Gower Street", will, needless to say, make nothing of the theological presuppositions of Augustine's discussion. I thus align myself with the philosophical radicals, as opposed to the noncoformists, among the founders of the University of London.

Another departure - though, here, this is more a matter of refinement rather than rejection-concerns Augustine notion of animi intentio. That the notion be adapted is dictated by our dropping Augustinian dualism. For, having done so, we may no longer conceive of animi intentio as the exercise of a power of an inextended, incorporeal, living soul. A question thus remains about whether anything may be found to play the role of animi intentio well enough to sustain the Augustinian 
solution to our aporia.

Let us begin, however, with the first two elements of the perceptual trinity, as they are the least controversial. Recall, Augustine distinguishes the object of perception from the perceiver's perceptual experience of it. Moreover, Augustine is a realist about the objects of perceptual experience. The objects of perception may be temporally and existentially prior to the perceiver's perception of them.

Augustine also claimed that the first two elements of the perceptual trinity are related in a certain way, that they are bound together in a unity. One natural way of understanding this Augustinian claim is that the object of perception is bound together with the perceiver's experience of it in the sense that the visual presentation of the object in the perceiver's experience of it is a kind of unity. Thus, Ardley (1958), in an unjustly neglected essay, describes perceptual apprehension as a kind of "communion". When contemporary philosophers speak of the object of perception as a constituent of the perceptual experience, they are emphasizing the unity of the perceptual experience with the existentially independent object.

Not only are the object of perception and the perceiver's perceptual experience of it bound together in the sense that the visual presentation of the object in perceptual experience is a kind of unity, but the perceptual experience assimilates to its object. Vision, for Augustine, is the body in-forming the sense. Moreover, the body in-forming the sense is meant to be the consequence of the two being bound together. Is there a natural way to understand perception as a mode of formal assimilation that is a consequence of the unity of the perceptual experience with its object?

Consider the following related question first. How are we to understand the image and likeness impressed on the sense by the form of the body? Talk of images may mislead, at least when addressed to modern ears. For there is a tendency to understand the image and likeness as a kind of inner representation. I hypothesize that this is what misleads O'Daly (1987, I06), in his still valuable and insightful study of Augustine's philosophy of mind, when he claims that "sense perception is perception of incorporeal images of the objects perceived". The object of perception is the external body, or perhaps its visible form, and not an inner likeness of it (for criticism of O'Daly see Brittain 2002; Matthews 20I4; Silva 20I4).

How are we to understand the image and likeness of the form of the body if it is not, indeed, to be understood as an inner representation? Begin with the object of perception to which the perceptual experience assimilates in presenting. The London Stone, residing in its illuminated casing on III Cannon Street, has a certain character, there are ways that it is like. Rough, gray, of diminished proportions, illuminated from above are all ways for things to be and ways the London Stone is visibly like. When I turn and look and see the London Stone, my perceptual experience is united with that stone. My perceptual experience, my seeing the 
stone, has a certain character, there is a way that it is like for me to undergo that experience (though see Snowdon 20IO). Moreover, the character of my perceptual experience, what it is like for me to undergo it, is not unrelated to the character of the object of my perceptual experience, what the stone is visibly like. Though, my visual experience is not exactly like the stone-it is neither rough, nor gray, nor of diminished proportions - nevertheless, what it is like for me to see, for example, the gray of the stone depends upon and derives from what that gray is like, at least relative to my partial perspective on it in the circumstances of perception.

The proposal, then, is that we understand perceptual assimilation as the deter mination, at least in part, of the phenomenological character of perceptual experience by the visible character of its object, relative to the perceiver's partial perspective in the circumstances of perception. So understood, the image and likeness of the form of the body is less an inner representation than the phenomenological character of the experience determined, in part, by the body's sensible and corporeal form.

Recall that the formal assimilation involved in perception was meant to be the consequence of the unity of the perceptual experience with its object. Can the formal assimilation of perception, as presently understood, plausibly be the consequence of the unity of the perceptual experience with its object? On the present understanding, the formal assimilation of perception to its object is the determination, at least in part, of the phenomenological character of perceptual experience by the visible character of its object, relative to the perceiver's partial perspective in the circumstances of perception. Moreover, the unity of the object and perceptual experience in being bound together is understood as the visual presentation in ex$^{-}$ perience of that object. Putting the two together, the explanatory claim would be that the visual presentation of the object and its visible character to the perceiver's partial perspective in the circumstances of perception determines, at least in part, the phenomenological character of the perception. While not uncontroversial, something like this claim is widely endorsed by naive realists and disjunctivists and is implicit in the common metaphor of the object "shaping" the perceiver's experience of it (for discussion of this metaphor and its history see Kalderon $2015 \mathrm{~b}$, chapter 9 ).

The binding of the perceptual experience to its object, with the consequence that the former formally assimilates to the latter, is itself subject to further explanation in the trinitarian account. It is the will of the soul that binds the sense to the distal body in the natural environment. How are we to understand this third element of the perceptual trinity, animi intentio, having dropped Augustine's dualism? And can any successor notion available to a relaxed naturalist play well enough the explanatory role of animi intentio in the trinitarian account? This is crucial to the final resolution of our aporia. The trinitarian account only offered a resolution of 
our aporia in virtue of the explanatory role of animi intentio. So it is only if we can find a successor notion available to a relaxed naturalist that plays well enough the explanatory role of animi intentio in constituting the unity of the perceptual trinity, that we can adapt for ourselves the Augustinian resolution of our aporia.

"In order to hear well," Maine de Biran observes, "it is necessary to listen" (Influence de l'habitude sur la faculté de penser; Boehm I929, 63-4). Echoing Maine de Biran, we might say, in order to see well, one must look. Looking is a notion available to a relaxed naturalist. Could looking, or some refinement of that notion, play the role of animi intentio?

Looking, like the will's direction of the sense, is an activity. Moreover, looking, like animi intentio, is an activity that is directed outwards. Looking is a voluntary intentional action that directs the perceiver's visual awareness to distal aspects of the natural environment. One may look with no particular end, just to see what there is to see. But one may also look at a particular thing, with the seeing of that thing as one's end. When, on Cannon Street, I turn, and look, and see the London Stone the activity of looking was operative prior to the stone coming into view, just as animi intentio is operative prior to binding the sense to the body so that the former may assimilate to the latter. And just as animi intentio fixes the sense to the body, looking at the London Stone fixes the explicit awareness afforded me by my perceptual experience on that stone, so that it is the conscious object of attention and, hence, available for epistemic appraisal. Not only does looking at the stone initiate my seeing of that stone, but looking sustains my seeing of it as well. Should I look away, I would cease to see the stone.

So it would seem, then, that looking plays three roles analogous to animi intentio in the trinitarian account. The confluence is potentially misleading, however. On Augustine's understanding of animi intentio and how it fulfils these roles, this is sufficient to understand how the will of the soul constitutes the unity of the perceptual trinity. And yet looking may have the features described consistent with not playing a constitutive role in the visual presentation of its object. Augustine's Christianised Platonism is doing some work in his account of perception. That animi intentio binds the sense to the body is a manifestation of its ontological superiority in being completely incorporeal. Having dropped Augustine's dualism debars us from making any similar claim. The difficulty is that animi intentio's constituting the unity of the perceptual trinity was part of what licensed us to judge that perception was something that the perceiver does, as opposed to something done to the perceiver. Can we find a constitutive role for looking in the visual presentation of its object?

My remaining remarks are speculative and are substantiated, if at all, elsewhere (Kalderon, 2015a).

Looking, understood as a psychological stance sustained by characteristic activ- 
ity, is an outward gaze, a looking into the distance, an outer-directed opening up to the visible. It can sometimes happen, if circumstances are propitious, that in looking outward, aspects of the natural environment, facing us from across the intervening distance, are presented to us in our visual experience.

I turn, and look, and see the London Stone. In so doing, I direct my gaze to that block of limestone. I look through the illuminated space, a space perceptually penetrated by my gaze, until I can no more. It is the resistance to my looking, my visual encounter with the perceptually impenetrable, that presents opaque objects arrayed in the distal environment. The London Stone resists my visual activity. The London Stone prevents me from seeing further. I can see nothing in it or through it.

However, not all limits to my gaze are external. There are internal limits to how far I may look into the distance. Other perceivers posses the capacity to look further than I can. And there are internal limits to my field of vision. So not all experienced limits to my gaze may disclose something external to me. So how is it possible for an experienced limit to my visual activity to disclose the perceptually impenetrable stone?

If the visual presentation of the perceptually impenetrable is due to the operation of sympathy, then we have the basis of an answer. It is only when I experience the stone's limit to my visual activity, its resistance to my gaze, its perceptual impenetrability, as a sympathetic response to a countervailing force, my gaze encountering an alien force that resists it, one force in conflict with another, like it yet distinct from it, that the perceptually impenetrable body discloses itself to visual awareness.

Sympathy, here, is not an emotional response to others, a kind of fellow-feeling, akin to compassion or pity - though, as Plotinus and Hume maintained, it may be its principle. Rather, the notion of sympathy being invoked is closer, instead, to the notion at work in Stoic and neo-Platonic physics, if more abstract and not at all reliant on on their vitalistic metaphysics (on sympathy in Stoic physics see Brouwer 2015, in Plotinus see Emilsson 2015). The present approach thus contrasts with Whitehead's (1978) who both explains perceptual prehension partly in terms of sympathy and embraces the association with emotion thus leading him to paradoxically portray perception as an outgrowth of blind emotion.

If the visual resistance of the stone is the means by which it is sympathetically presented in visual experience, then in being sympathetically presented with an external body, the perceiver is naturally attending to the external body, the object of visual perception. In visual perception, the perceiver is explicitly aware of the object of perception. They consciously attend to it in such a way that it is open for epistemic appraisal. And in affording the perceiver explicit awareness of it, that object shapes the perceiver's perceptual experience, at least relative to their partial 
perspective in the circumstances of perception.

The speculative suggestion, then, was that looking may play a constitutive role in the visual presentation of its object, if visual presentation is understood to be a sympathetic reaction to an experienced limit to the perceiver's activity. And if looking does indeed play this constitutive role in visual presentation, if it constitutes the unity of the perceptual trinity, then we are fully licensed to say that in looking and seeing what they do, perception is something the perceiver does, and not something done to the perceiver. And this remains true even if the object of perception is a causal antecedent of the perceptual experience that they undergo.

If sensory presentation is a distinctive kind of unity, a "communion" with its object, then visual presentation is more distinctive still. Insofar as visual presentation is governed by the principle of sympathy, it is a mode of being-with. Visual presentation is a mode of being-with insofar as it unites potentially distinct substances (understood as being or essentia), the object of perception and the perceiver whose experience presents it. Sartre's overly aggressive conception of the look, in L'Etre et le néant: Essai d'ontologie phénoménologique, blinds him to this possibility. Sartre fails to see how the look's coming into conflict with its object may be the means of the latter's sympathetic presentation to the former. (See Jay 1994, chapter 5, especially 287, where he remarks that Heidegger's conception of mit-sein was, perhaps, too irenic for Sartre.) Turning, and looking, and seeing the London Stone is a way of being with that stone. Visual presentation is a way of being with that which resists our gaze.

\section{References}

Gavin Ardley. The nature of perception. Australasian fournal of Philosophy, 36(3): I89-200, I958. doi: I0.1080/00048405885200231. (document)

Margaret Donaldson Boehm. The Influence of Habit on the Faculty of Thinking. Williams \& Wilkins, Baltimore, MD, I929. (document)

Charles Brittain. Non-rational perception in the Stoics and Augustine. Oxford Studies in Ancient Philosophy, 22:253-308, Summer 2002. (document)

Alexander Broadie. Robert Kilwardby O.P. On Time and Imagination, volume IX 2 of Auctores Britannici Medii Aevi. Oxford University Press for the British Academy, Oxford, I993.

René Brouwer. Stoic sympathy. In Sympathy, A History, chapter I. Oxford University Press, Oxford, 2015. (document) 
Richard Cross. Duns Scotus's Theory of Cognition. Oxford University Press, Oxford, 20I4. (document)

Eyjólfur Kjalar Emilsson. Plotinus on sympatheia. In Sympathy, A History, chapter 2. Oxford University Press, 2015. (document)

Luigi Gioia. The Theological Epistemology of Augustine's De Trinitate. Oxford Theological Monographs. Oxford University Press, Oxford and New York, 2008. (document)

R.D. Hicks. Aristotle De Anima, with Translation, Introduction, and Notes. Cambridge University Press, Cambridge, 1907.

Martin Jay. Dowencast Eyes, The Denigration of Vision in Twentieth-Century French Thought. University of California Press, 1994. (document)

Mark Eli Kalderon. Parousia, sympathy and sensory presentation. forthcoming from Oxford University Press, 20I5a. (document)

Mark Eli Kalderon. Form without Matter, Empedocles and Aristotle on Color Perception. Oxford University Press, Oxford, 2015b. (document)

Bonnie Dorrick Kent. Airstotle and the Franciscans: Gerald Odonis' commentary on the Nichomachean Ethics. PhD thesis, Columbia University, New York, 1984. (document)

Gareth B. Matthews. Knowledge and illumination. In David Vincent Meconi and Eleonore Stump, editors, The Cambridge Companion to Augustine, chapter 13, pages I7I-I85. Cambridge University Press, Cambridge, 20I4. (document)

Gareth B. Matthews and Stephen McKenna. Augustine On the Trinity Books 8-I5. Cambridge Texts in the History of Philosophy. Cambridge University Press, Cambridge, 2002. (document)

Gerard O'Daly. Augustine's Philosophy of Mind. University of California Press, Berkeley and Los Angeles, 1987. 3, (document)

Robert Pasnau. Theories of Cognition in the Later Middle Ages. Cambridge University Press, Cambridge, 1997. (document)

José Filipe Silva. Augustine on active perception. In José Filipe Silva and Mikko Yrjönsuuri, editors, Active Perception in the History of Philosophy, From Plato to Modern Philosophy, Studies in the History of Philosophy of Mind, chapter 5, pages 79-98. Springer, Cham Heidelberg New York Dordrecht London, 20I4. (document) 
José Filipe Silva and Juhana Toivanen. The active nature of the soul in sense perception: Robert Kilwardby and Peter Olivi. Vivarium, 48:245-278, 20IO. (document)

José Filipe Silva and Mikko Yrjönsuuri. Active Perception in the History of Philosophy, volume I4 of Studies in the History of Philosophy of Mind. Springer, 20I4. (document)

Paul Snowdon. On the what-it-is-like-ness of experience. Southern fournal of Philosophy, 48(I):8-27, 2010. (document)

Leen Spruit. Species Intelligibis From Perception to Knowldge, volume I of Brill's Studies in Intellectual History. E.J. Brill, Leiden, New York, and Kóln, 1994. (document)

Katherine H. Tachau. Vision and Certitude in the Age of Ockham: Optics, Epistemology, and the Foundations of Semantics, $1250^{-1}$ 345. Studien und Texte zur Geistesgeschichte des Mittlealters. E.J. Brill, Leiden, 1988. (document)

Juhana Toivanen. Perception and the Internal Sneses, Peter of fohn Olivi on the Cognitive Functions of the Soul, volume 5 of Investigating Medieval Philosophy. Brill, Leiden and Boston, 2013. (document)

Alfred North Whitehead. Process and Reality, An Essay in Cosmology, Gifford Lectures Delivered in the University of Edinburgh During the Session 1927-28, A Corrected Edition. The Free Press, A Division of Macmillan Publishing Co., Inc., New York, 1978. (document)

Bernard Williams. The truth in relativism. In Moral Luck, pages I32-I44. Cambridge University Press, Cambridge, 198r. (document) 